\title{
Is There a Correlation between the Quality of Life of Old People and Their Attitude to Aging?
}

\author{
Aynur Uysal Toraman ${ }^{1}$ (D) , Gülengül Mermer ${ }^{1}$ (iD , Aslı Kalkım ${ }^{1}$ (D)
}

${ }^{1}$ Ege University Faculty of Nursing, Department of Public Health Nursing, Bornova, Izmir, Turkey

Aynur UYSAL TORAMAN

Gülengül MERMER

Aslı KALKIM

\section{Correspondence: Aslı Kalkım}

Ege University Faculty of Nursing, Department of Public Health Nursing, Bornova, Izmir, Turkey Phone: +902323115587

E-mail: aslikalkim@gmail.com

\begin{abstract}
Objective: The aim of the research was to the correlation between the quality of life of old people and their attitude to aging.

Methods: The descriptive relational study was conducted between July and November 2016 at a nursing home in the province of Izmir. The population of the study consisted of the old people $(n=308)$, and the sample was formed from the 147 individuals. The instruments were socio-demographic questionnaire, the World Health Organization Quality of Life Module for Old People (WHOQOL-OLD), and the Turkish version of the World Health Organization Europe Aging Attitudes Questionnaire (AAQ). Descriptive statistical methods, Spearman correlation analysis and multiple regression analysis were used to analyze the data.
\end{abstract}

Results: The mean age of the old people was $74.32 \pm 6.65$ years and $64.6 \%$ were male. The total mean scores of the old people were $60.49 \pm 16.99$ on WHOQOL-OLD and $52.84 \pm 14.17$ on AAQ. A strong positive correlation was found between these two scores $(r=0.827, p<0.001)$. It was seen in the multiple regression analysis that the old people's attitudes to aging were a predictive factor of their quality of life $\left(F=53.114, p<0.001, R^{2}=0.70\right)$.

Conclusion: These results indicate that there is a significant correlation between the quality of life and attitudes toward aging in nursing home residents, and that their attitudes to aging are a significant variable explaining their quality of life.

Keywords: Aging; attitude; nursing home; quality of life

\section{Yaşııların Yaşam Kalitesi ile Yaşlanmaya Karşı Tutumları Arasında Bir ílişki Var Mı?}

ÖZET

Amaç: Araştırmanın amacı, yaşlı bireylerin yaşam kalitesi ile yaşlanmaya karşı tutumları arasındaki ilişkiyi belirlemektir.

Yöntem: Tanımlayıcı ilişkisel araştırma, Temmuz-Kasım 2016 tarihleri arasında İzmir ilindeki bir huzurevinde gerçekleştirilmiş̧tir. Araştırmanın evreni 308 yaşlı olup, örneklemi 147 yaşlı birey oluşturmuştur. Veri toplama araçları sosyo-demografik anket, Dünya Sağlık Örgütü Yaşıılar için Yaşam Kalitesi Modülü (WHOQOL-OLD) ve Dünya Sağlık Örgütü Avrupa Yaşlanma Tutumları Anketi (AAQ)'nin Türkçe versiyonudur. Verilerin analizinde tanımlayıcı istatistiksel yöntemler, Spearman korelasyon analizi ve çoklu regresyon analizi kullanılmıştır.

Bulgular: Yaşı̧ı bireylerin \% 64.6'sı erkek olup, yaş ortalaması $74.32 \pm 6.65$ yıldı. Yaşlı bireylerin toplam puan ortalamaları WHOQOL-OLD $60.49 \pm 16.99$ ve AAQ 52.84 \pm 14.17 olup; bu iki puan arasında güçlü bir pozitif korelasyon bulunmuştur $(r=0.827, p<0.001)$. Çoklu regresyon analizinde yaşı ı bireylerin yaşlanmaya karşı tutumlarının yaşam kalitelerini yordayıcı bir faktör olduğu görülmüştür ( $\left.F=53.114, p<0.001, \mathrm{R}^{2}=0.70\right)$.

Sonuç: Bu sonuçlar huzurevinde yaşayan yaşlı bireylerin yaşam kaliteleri ile yaşlanmaya yönelik tutumları arasında anlamlı bir ilişkinin olduğunu ve yaşlanmaya karşı tutumlarının yaşam kalitelerini açıklayan önemli bir değişken olduğunu göstermektedir.

Anahtar Kelimeler: Yaşlanma, tutum, huzurevi, yaşam kalitesi

$\begin{array}{ll}\text { Received } & : 31 \text { May } 2021 \\ \text { Accepted } & : 2 \text { December } 2021\end{array}$


$\mathbf{T}$ he proportion of old people in the world is rapidly increasing. It has been reported that in the world in general there are 600 million people aged 60 and over, and that by the year 2025 this number will double. It is estimated that $80 \%$ of this population live in developing countries (1). In Turkey, a developing country, the proportion of old people in the population was $6.8 \%$ in 2008 , and in 2020 this proportion had risen to $9.5 \%$ (2). According to this information, the proportion of old people in the country is estimated to reach $10.2 \%$ by 2023 (3). The city of Izmir, where the research was performed, is in the west of Turkey, and is Turkey's third largest city. At the same time it is the second city in terms of people aged over 100, with 236 centenarians, and the proportion of old people in the population is higher than the average for Turkey, which is $10.1 \%(2)$.

In the present day, as conditions of life improve, lifestyles and family values change and the number broken families increases, there is also an increase in the number of old people living alone (4-6) or in nursing homes (7). Researches have shown that being alone has a negative effect on physical and psychological health, and decreases the quality of life $(6,8)$.

The WHO reports that people in industrialized countries become rich before they age, whereas in developing countries they age before they become rich. In the whole world, preparation is recommended against the consequences of this process of demographic change of increasing aging (9). Providing independence for old people, developing their active life and contributing to their social and economic life, that is, an approach of adding quality to life, has been developed (10). For this reason, assessing the quality of life of old people is an important public health issue in order to encourage active aging (9).

Along with aging, disability (11), economic problems and social status changes, and other related factors which increase dependency raise the importance of the quality of life $(12,13)$. Along with progressively increasing life expectations, it has become more important to determine the factors affecting the quality of life for healthy aging. Looking generally at studies performed on the quality of life of old people, it is seen that certain traits such as age, gender, educational level (14-16), chronic illnesses or physical disabilities (14), state of physical activity (6), physical changes and psychological losses (12), social support and loneliness and economic condition $(6,16)$ are factors which affect the quality of life of old people.
Another significant factor affecting the quality of life is the attitude of old people about old age $(15,17)$. Along with social changes, the perception of old age has also changed. For this reason, not only old people's experience of old age but also their attitude to it has become an important indicator of healthy aging (17). Studies have found that a positive attitude to aging is more effective than many other variables on the length of life, that a negative attitude to aging is a variable which has a direct effect on the quality of life $(15,18)$, that there is a correlation between the sub-dimensions of attitude to aging and quality of life $(12,15,19)$, that there is a significant correlation between the attitude to aging and quality of life $(15,19)$, and that the state of perception of aging affects the level of quality of life (20).

Quality of life and attitudes to old age have been studied in Turkey by descriptive research $(13,20,21)$, but there have been few studies explaining the effects of attitudes to old age on the quality of life $(15,22,23)$. Determination of the attitudes of old people to old age and examining its relationship to the quality of life by nurses who take on the important roles of preserving the quality of life of old people and enabling them to maintain an active life is thought to be a significant need in setting up and providing health care for old people. Also, this is the first study conducted in the west of Turkey.

\section{Objective}

The research aim was to the correlation between the quality of life of old people and their attitude to aging.

\section{MATERIALS and METHODS}

\section{Study Design and Samples}

The research was a descriptive relational type of study. It was performed between July and October 2016 at a nursing home of Izmir City Municipality, which was determined by the purposive sampling method. The nursing home had a 304 bed capacity and 270 resident old people.

The population of the study was the 270 old people resident in the nursing home, 44 of whom had serious illnesses. It was intended to reach the whole of this population, and so no sampling method was used. Old people with cognitive problems (dementia, mental retardation, etc.) to the extent that they could not understand or answer the questions ( $n=42)$, those with hearing loss at an advanced level $(n=31)$, those who were not present in the nursing home or who were on leave at the time of the research $(n=19)$, and those who did not agree to participate $(n=25)$ 
were excluded from the study, so that 147 individuals were included.

\section{Data Collection}

Data collection forms were an old people's question form, the World Health Organization Quality of Life Module for Old People (WHOQOL-OLD), and the Turkish version of the World Health Organization - Europe Aging Attitude Questionnaire (AAQ). Collection of data was performed with face to face interviews by the researchers with the old people in the nursing home.

\section{Old People's Question Form}

This form was developed by the researchers in the light of the literature $(13,22,23)$, and consisted of 11 questions to determine the old people's socio-demographic characteristics and their medical history.

\section{World Health Organization Quality of Life Old People's Module (WHOQOL-OLD)}

This consisted of six dimensions and 24 questions. The dimension of Sensory Functions consisted of questions number 1, 2, 10 and 20, and evaluated sensory functions and the effects on their loss on the quality of life. The dimension of Autonomy included questions 3, 4, 5 and 11 . This covered independence at an old age, and expressed the ability to live independently. The dimension of Past, Present and Future Activities consisted of questions number 12,13, 15 and 19, and showed the satisfaction obtained from successes in life and the view of the future. The dimension of Social Participation included questions 14, 16,17 and 18, and described in particular the ability to participate in the activities of daily life. The dimension of Death and Dying comprised questions number $6,7,8$ and 9 , and related to concerns, worries and fears to do with death and dying. The dimension of Closeness included questions 21, 22, 23 and 24, and evaluated the skill of forming personal and private relationships. The answers given to each question scored from 1 to 5 on a 5-way Likert-type scale, and the possible dimension score was between 4 and 20. Also, the total score was calculated from the total of the values of each separate score. A higher score indicated a better quality of life. The validity and reliability of the Turkish version of the form was tested by Eser et al. (2010), and alpha values were found of 0.85 for the general structure of the scale (24). In this research, the Cronbach alpha value of the scale was found to be 0.73 .
Europe Aging Attitude Questionnaire (AAQ)

This questionnaire consisted of 24 questions and three sub-dimensions (psycho-social loss, bodily change and psycho-social development), each with eight questions. The dimensions were evaluated with a score of between 8 and 40 . Alongside the scores obtained, the total scale score could be calculated. When the score for the psychosocial loss dimension was inverted, a higher score indicated a positive change in attitude for that dimension. Validity and reliability for the Turkish-language form were tested in this country by Eser et al. (2011) (17). In this study the Cronbach alpha value was found to be 0.56 .

\section{Data Analysis}

The data were analyzed with SPSS version 21.0. for Windows (SPSS, Inc., Chicago IL, USA). Data analysis made use of numerical and percentage distribution, means and standard deviation in descriptive statistical evaluation. Spearman correlation analysis was used to examine the relation between scales, and multiple regression analysis to determine the best explanatory factors.

\section{Study Ethics}

Written permission was obtained from the Scientific Ethics Committee of University Nursing Faculty (Approval dated Jun 28, 2016; Number: 2016-214) and from the management of the nursing home. The purpose and benefits of the research were explained to the old people who took part in the research. Informed consent was given by participants and the questionnaire forms were completed anonymously. The research was carried out in accordance with the Helsinki Declaration Principles.

\section{RESULTS}

Socio-demographic characteristics and health histories of the old people

The mean age of the old people was $74.32 \pm 6.65$ ( $\mathrm{min}=65$, $\max =91$ ), and $64.6 \%$ were male. It was found that $58.5 \%$ were educated to primary school level, $74.1 \%$ were retired and $43.5 \%$ had an income which was less than their expenditures. Most $(76.9 \%)$ of the $68 \%$ who were married had children; the mean number of children was $1.73 \pm 0.73$ ( $\min =1$, $\max =6$ ), and $52.2 \%$ saw their children occasionally (Table 1). The old people had spent a mean of $64.56 \pm 53.80$ ( $\min =1, \max =276)$ months in the old people's home. Most of them (82.3\%) had at least one chronic illness, the most frequent of which were diabetes $(30.6 \%)$, hypertension (29.8\%), and heart disease (29.8\%) (Table 1). 


\section{Table 1. Old people by socio-demographic characteristics}

Characteristics \begin{tabular}{l|l}
$\mathbf{N}$ & $\%$ \\
\hline
\end{tabular}

\section{Age group}

\begin{tabular}{|l|c|c|}
\hline 65-74 years (younger) & 75 & 51.0 \\
\hline $75-84$ years (medium) & 62 & 42.2 \\
\hline 85 years and above (older) & 10 & 6.8 \\
\hline Gender & 52 & 35.4 \\
\hline Female & 95 & 64.6 \\
\hline Male & &
\end{tabular}

\section{Education}

\begin{tabular}{|l|c|c|}
\hline Primary & 86 & 58.5 \\
\hline Middle school & 40 & 27.2 \\
\hline High school & 17 & 11.6 \\
\hline University & 4 & 2.7 \\
\hline
\end{tabular}

\section{Marital status}

\begin{tabular}{|l|c|c|}
\hline Married & 100 & 68.0 \\
\hline Single & 47 & 32.0 \\
\hline Working status & 109 & 74.1 \\
\hline Retired & 38 & 25.9 \\
\hline Other (not working, not retired) & \multicolumn{2}{|l|}{} \\
\hline Income status & 64 & 43.5 \\
\hline Income < Expenditure & 59 & 40.1 \\
\hline Income = Expenditure & 24 & 16.3 \\
\hline Income > Expenditure & & \\
\hline Number of children & 34 & 23.1 \\
\hline 0 & 58 & 39.5 \\
\hline 1-2 & 55 & 37.4 \\
\hline 3 or more & & \\
\hline
\end{tabular}

\begin{tabular}{|l|c|c|}
\hline Frequency of seeing children $(\mathbf{n}=\mathbf{1 1 3})$ \\
\hline Not at all & 22 & 19.5 \\
\hline Occasionally & 59 & 52.2 \\
\hline Frequently & 32 & 28.3 \\
\hline
\end{tabular}

\section{Length of residence in nursing home}

\begin{tabular}{|l|c|c|}
\hline $1-10$ years & 128 & 87.1 \\
\hline $11-20$ years & 17 & 11.6 \\
\hline 21 years or more & 2 & 1.4 \\
\hline Total & $\mathbf{1 4 7}$ & $\mathbf{1 0 0 . 0}$ \\
\hline
\end{tabular}

Quality of Life and Attitudes to Aging of the Old People

Table 2 shows the mean, minimum and maximum values of the scores obtained by the old people on the WHOQOLOLD and AAQ scales. The mean total scores of the old people were found to be $60.49 \pm 16.99$ on WHOQOL-OLD and $52.84 \pm 14.17$ on $A A Q$.

\begin{tabular}{|c|c|c|c|}
\hline $\begin{array}{l}\text { Scale and } \\
\text { sub-dimensions }\end{array}$ & Mean & SD & Min -Max \\
\hline WHOQOL-OLD & 60.49 & 16.99 & $18.75-92.71$ \\
\hline Sensory functions & 67.77 & 23.21 & $25-100$ \\
\hline Autonomy & 55.70 & 20.07 & $6.25-100$ \\
\hline $\begin{array}{l}\text { Past, present and future } \\
\text { activities }\end{array}$ & 56.08 & 19.88 & $0-100$ \\
\hline Social participation & 52.85 & 21.10 & $0-100$ \\
\hline Death and dying & 67.26 & 28.90 & $6.25-100$ \\
\hline Closeness & 63.31 & 18.61 & $12.5-100$ \\
\hline AAQ & 53.84 & 14.17 & $28-83$ \\
\hline Psychosocial loss & 18.79 & 7.93 & $8-37$ \\
\hline Bodily change & 24.34 & 6.36 & $11-37$ \\
\hline Psychosocial development & 24.29 & 4.23 & $12-38$ \\
\hline
\end{tabular}

Correlation between Quality of Life and Attitudes to Aging in the Old People

The correlation between the total WHOQOL-OLD and AAQ scores was positive, very strong and significant at a high level $(r=0.827, p<0.001)$. At the same time, correlations between the total WHOQOL-OLD score and the sub-dimensions of AAQ were as follows: psycho-social loss, strongly negative $(r=-0.715, p<0.001)$; body change, strongly positive $(r=0.780, p<0.001)$; psycho-social development, weakly positive $(r=0.272, p<0.01)$. A statistically high level of correlation was found (Table 3).

\section{A Variable Explaining the Old People's Quality of Life: Their Attitudes to Aging}

The old people's quality of life was significantly related to their attitudes to aging $\left(F=103.228, p<0.001, R^{2}=0.68\right)$. Significant predictors of the old people's quality of life included the AAQ sub-dimensions of psychosocial development, psychosocial loss and bodily change (Table 4). 
Table 3. Correlations between WHOQOL-OLD and AAQ

\begin{tabular}{|c|c|c|c|c|}
\hline Scale and sub-dimensions & Psychosocial loss & Bodily change & $\begin{array}{l}\text { Psychosocial } \\
\text { development }\end{array}$ & AAQ \\
\hline Sensory functions & $-0.576^{* * *}$ & $0.556^{* * *}$ & $0.064 p=0.444$ & $0.583^{* * *}$ \\
\hline Autonomy & $-0.633^{* * *}$ & $0.687^{* * *}$ & $0.303^{* * *}$ & $0.750 * * *$ \\
\hline Past, present and future activities & $-0.665^{* * *}$ & $0.704^{* * *}$ & $0.289 * * *$ & $0.762 * * *$ \\
\hline Social participation & $-0.570^{* * *}$ & $0.699^{* * *}$ & $0.394^{* * *}$ & $0.754 * * *$ \\
\hline Death and dying & $-0.505^{* * *}$ & $0.514^{* * *}$ & $0.103 p=0.216$ & $0.543 * * *$ \\
\hline Closeness & $-0.426^{* * *}$ & $0.511^{* * *}$ & $0.136 p=0.100$ & $0.503^{* * *}$ \\
\hline WHOQOL-OLD & $-0.715 * * *$ & $0.780 * * *$ & $0.272 * *$ & $0.827 * * *$ \\
\hline
\end{tabular}

Table 4. Regression model predicting old peoples' quality of life

\begin{tabular}{|c|c|c|c|}
\hline Factors & $\begin{array}{l}\text { Beta } \\
\mathbf{3 1 . 6 3 6}\end{array}$ & $\begin{array}{l}\text { t-statistics } \\
\mathbf{4 . 3 8 9}\end{array}$ & $\begin{array}{l}\mathbf{p} \text {-value } \\
\mathbf{. 0 0 0 ^ { * * * }}\end{array}$ \\
\hline Psychosocial loss & -1.046 & -6.211 & $0.000^{* * *}$ \\
\hline Bodily change & 0.904 & 4.229 & $0.000^{* * *}$ \\
\hline $\begin{array}{l}\text { Psychosocial } \\
\text { development }\end{array}$ & 1.092 & 5.095 & $0.000^{* * *}$ \\
\hline $\mathrm{R}^{2}=0.684 \quad \mathrm{~F}(3.147)=103.228^{* * *}$ & \multicolumn{4}{|l|}{ Durbin-Watson $=1.632$} \\
\hline${ }^{* * *} \mathrm{p}<0.001$ \\
\hline
\end{tabular}

\section{DISCUSSION}

This research explained the quality of life of older people living in a nursing home in the west of Turkey and its relation to their attitudes to aging. The old people's attitude to aging (AAQ mean total score $52.84 \pm 14.17$, max. score 120) was at slightly medium level. In a study by Top and Dikmetaş (2015), this proportion was at a medium level in a similar age group of residents of an old people's home, while Bryant et al. (2012) in a study of 421 people in Australia aged 60 and above, found a positive attitude. In these studies, a positive attitude was found to be correlated to satisfaction with life, good physical and mental health, and low levels of anxiety and depression $(14,25)$ and to affect cognitive performance and preventive health behaviors (26).

It was seen in the study that the attitudes of the old people to bodily change and psychosocial development were more positive than that to psychosocial loss. Also, it was seen that the attitudes of old people to bodily change in a study in Turkey by Eser et al. (2011) and to psychosocial developments in studies by Özyurt et al. (2012) and Top and Dikmetaş (2015), also performed in this country, were more positive. Similar result was obtained in study carried out in in rural and regional Australia (25). In all studies, old people had fewer positive attitudes to psychosocial losses.
The mean total score of the old people on the WHOQOLOLD was $60.49 \pm 16.99$, and the maximum score for the overall scale was 120 . This mean score shown that the old people's QOL was at a medium level. In Turkey, studies by Altay, Çavuşoğlu, Çal (2016) and Top and Dikmetaş (2015) found a lower score, while a study by Eser, Saatli, Eser, Baydur, Fidaner (2010) found a higher one. Comparing with researches carried out in other countries, it was seen that the quality of life found in a study conducted with 220 old people in a rural area of Tehran was lower than that in this study (27).

Maintaining functional independence is an important factor for old people in terms of quality of life. Viewed from this perspective, it was seen that sensory function, a subdimension of the quality of life of old people, obtained higher scores in the study than the other sub-dimensions. It may be thought that because the mean age of the old people was $74.32 \pm 6.65$ and more than half of them were in the younger old-age group, their sensory function losses were less. At the same time, similar finding was encountered in the literature showing that sensory function was lower at a more advanced age (13). Also, the old people were living in an nursing home and benefitted from organized health services, their access to health services was easy, and problems relating to sensory function were diagnosed and treated early. Similarly, sensory function was found to be the highest among the quality of life subdimensions in studies with residents of nursing homes by Şahin and Emiroğlu (2013), with old people living in an urban area by Tavares, Bolina, Dias, Ferreira, Haas (2014) (28), and by Altay, Çavuşoğlu, Çal (2016). Differently, Top ve Dikmetaş (2015) and Top, Eriş, Kabalcıoğlu (2012) were found to be the lowest. This result can be explained by the greater age of the group of old people, and along with this the increase in chronic illness and dependence. 
It was seen in the study that the old people had high scores on death and dying, one of the sub-dimensions of quality of life. Death is seen in Western societies as a chance event which it is not talked about, while in Eastern societies on the contrary death is accepted as a natural phenomenon (24). It was seen in this study too that death was accepted by the old people in a way that could be seen as fatalistic as a natural, unavoidable process, and that this perception had a positive effect on the quality of life. In studies by Kritika, Aggarwal, Semwal (2017) (27), Bilgili and Arpacı (2014) (29), the sub-dimension of death and dying had the highest score. Differently, Eser (2010) found it to be the lowest.

Similar to a previous study (6), our research showed that social support was an important factor in quality of life, with the old people reporting that a higher level of social support correlated to a higher quality of life (24). In this way it is thought that the result that old people's social participation was low arose from their restricted field of social activity in society because they were in an nursing home. On this topic, Şahin and Emiroğlu (2014) found a correlation between the ways old people in an nursing home spent their time and their quality of life, and reported that the quality of life increased with an increase in the number of activities in the nursing home. Similar to the results of our study, social participation was found to be low in old people living in rural areas by Tavares, Bolina, Dias, Ferreira, Haas (2014). For this reason it is thought that increasing the social interaction of people living in nursing homes is an important approach in improving their quality of life.

In parallel with the level of development in societies, the perception of old age in traditional societies as maturity and wisdom has given way to a perception of it as deficiency, weakness and dependence (17). It was found that positive perceptions of old age by old people extended their lives. For this reason, the attitude of old people towards old age is an important indicator for healthy aging $(17,21)$.

The results showed significant relationship between quality of life and attitudes toward aging for old people in a city of Turkey. Physical change, psychosocial loss and psychological growth related to attitudes were significant predictors $(68 \%)$ of their quality of life. Eser, Saatli, Eser, Baydur, and Fidaner (2010) in Turkey, Low, Molzahn, and Schopflocher (2013), Kalfoss, Low, Molzahn (2010) in Canada and Norway, found significant relationship between quality of life and attitudes toward aging in old people. Additionally, Bryant et al. (2012) reported that a positive attitude to aging had a positive effect on physical and mental health. Studies performed by Top and Dikmetaş (2015) in the north of Turkey and by Kalfoss, Low, Molzahn AE (2010) in Norway support this result. Kalfoss, Low, and Molzahn (2010) found that all the subscales of WHOQOL-Older Adults Module (OLD) and WHO-AAQ correlations were significant in the Canadian and Norwegian samples, the lowest being between psychosocial loss and psychosocial growth for both Canada $(r=.363)$ and Norway $(r=.132)$.

The old people's attitude to the sub-dimension of psychosocial development was the most important variable explaining their quality of life. Psychosocial development can be said to be a process which shows that physical, psychological and social changes are accepted by old people.

\section{CONCLUSION}

In conclusion, As a result, as the elderly population increases, improving the quality of life of the elderly becomes an important requirement in health services. By determining the factors affecting the quality of life of the elderly, preventive health services can be provided to the elderly at risk in the early period. The research results show that there is a significant relationship between quality of life and attitudes towards aging and that their attitudes towards aging are an important variable explaining the quality of life. It is thought that preparation of old people for the aging process by health professionals and in this process the creation of a positive attitude to aging could have an important positive effect on the quality of life of old people. Knowledge of the relationships between the quality of life of old people and their attitudes towards aging will contribute to consideration of strategies to improve the quality of life of old people on the part of professionals and policy makers concerned with the aged. It is thought that developing attitudes to aging at a societal and individual level will help to reach the target of successful aging.

\section{Limitation of the Study}

The limitations of the research are that it was limited to old people living in a nursing home, that participation was low, and that data was dependent on the self-reporting of the old people. 


\section{DECLARATIONS}

\section{Financial Disclosure/Statement \\ None declared}

\section{Conflict of Interest \\ All authors declare no conflict of interest.}

\section{Authorship Contribution}

All authors contributed equally while this study preparing.

\section{REFERENCES}

1. Older people and primary health care [Internet]. Geneva:WHO;2016 [cited 2016 Jun 10]. Available from: http://www.who.int/ageing/ primary_health_care/en/

2. Statistics for elderly people, 2020 [Internet]. Turkish Statistical Institution News Bulletin, 2015 [cited 2021 March 18]. Available from: http://www.tuik.gov.tr

3. Statistics for elderly people, 2014 [Internet]. Turkish Statistical Institution News Bulletin, 2014 [cited 2016 Jun 08]. Available from: http://www.tuik.gov.tr

4. Aylaz R, Aktürk Ü, Erci B, Öztürk H, Aslan H. Relationship between depression and loneliness in elderly and examination of influential factors. Arch Gerontol Geriatr. 2012;55(3):548-54.

5. Arslantas H, Adana F, Abacigilergin F, Kayar D, Acar G. Loneliness in elderly people, associated factors and its correlation with quality of life: A field study from Western Turkey. Iran J Pub Health. 2015;44(1):43-50.

6. Chen $Y$, Hicks A, While AE. Quality of life and related factors: A questionnaire survey of older people living alone in Mainland China. Qual Life Res. 2014;23(5):1593-602.

7. Kavlak Y, Demirtaş RN. Effects of daily life activities, depression and cognitive status of older people living in nursing homes on their life quality. Sakarya Med J. 2012;2(1):30-6.

8. Lauder W, Sharkey S, Mummery K. A community survey of loneliness. J Adv Nurs. 2014;46(1):88-94.

9. Active ageing, a policy framework [Internet]. World Health Organization, Geneva: 2002 [cited 2016 Dec 07]. Available from: http://apps.who.int/iris/bitstream/10665/67215/1/ WHO NMH NPH_02.8.pdf.

10. Bowling, A. The psychometric properties of the Older People's Quality of Life Questionnaire, compared with CASP-19 and the WHOQOLOLD. Curr Gerontol Geriatr Res. 2009. doi:10.1155/2009/298950.

11. Singh I, Morgan K, Belludi G, Verma A, Aithal S. Does nurses'education reduce their work-related stress in the care of older people? J Clin Gerontol Geriatr. 2015;6(1):34-7.

12. Low G, Molzahn AE, Schopflocher D. Attitudes to aging mediate the relationship between older peoples' subjective health and quality of life in 20 countries. Health Qual Life Outcomes. 2013;11(1):1.

13. Şahin NE, Emiroğlu ON. Quality of life and related factors of older people in nursing home. Hacet Univ Hem Fak Derg. 2014:57-66.

14. Kisvetrová $H$, Herzig R, Bretšnajdrová $H$, Tomanová J, Langová $K$, Školoudík D. Predictors of quality of life and attitude to ageing in older adults with and without dementia, Aging \& Mental Health, 2019. DOI:10.1080/13607863.2019.1705758

15. Aslan GK, Altıntaş HK, Çınar İÖ, Veren Afttitudes to ageing and their relationship with quality of life in older adults in Turkey. Psychogeriatrics 2019;19:157-164.

16. Sun XJ, Lucas H, Meng QY, Zhang YG. Associations between living arrangements and health-related quality of life of urban elderly people: a study from China. Qual Life Res. 2011;20:359-69.
17. Eser E, Gerçekoğlu GS, Eser S, Fidaner C, Baysan P, Pala T, et al. Psychometric properties of the Turkish version (AYTA-TR) of The WhoEurope Attitudes of Aging (EAAQ) Questionnaire. Turk J Geriatr. 2011;14:101-10.

18. Trigg R, Watts S, Jones R, Tod A, Elliman R. Self-reported quality of life ratings of people with dementia: the role of attitudes to aging. Int Psychogeriatr 2012;24(7):1085-93.

19. Kalfoss $M H$, Low G, Molzahn AE. Reliability and validity of the attitudes to ageing questionnaire for Canadian and Norwegian older adults. Scand J Caring Sci. 2010;24(s1):75-85.

20. Altay B, Çavuşoğlu F, Çal A. The factors affecting the perception of elderly patients towards health, quality of life and health-related quality of life. TAF Prev Med Bull. 2016;15(3):181 (in Tukish).

21. Özyurt BC, Tunç B, Hatipoğlu S. Age-related attitudes of elderly people: Example of an urban and rural regions in Manisa. Akademik Geriatri 2013;5:29-37.

22. Top $M$, Dikmetas $E$. Quality of life and attitudes to ageing in Turkish older adults at old people's homes. Health Expect 2015;18:288-300.

23. Top $M$, Eriş $H$, Kabalcıoğlu F. Quality of Life (QOL) and attitudes toward aging in older adults in Şanlıurfa, Turkey. Res Aging. 2012:1-30.

24. Eser S, Saatlı G, Eser E, Baydur H, Fidaner C. The reliability and validity of the Turkish version of the World Health Organization Quality of Life Instrument-Older Adults Module (WHOQOL-Old). Turk Psikiyatri Derg. 2010;21(1):37-48.

25. Bryant C, Bei B, Gilson K, Komiti A, Jackson H, Judd F. The relationship between attitudes to aging and physical and mental health in older adults. Int Psychogeriatr 2012;24(10):1674-83.

26. Korkmaz Aslan G, Kartal A, Özen Çınar I, Koştu N. The relationship between attitudes toward aging and health-promoting behaviours in older adults. Int J Nurs Pract. 2017;23:e12594.

27. Kritika KR, Aggarwal P, Semwal J. Quality of Life (QOL) among the elderly in rural Dehradun. Indian J Comm Health 2012;29(1):00-00.

28. Tavares DMS, Bolina AF, Dias FA, Ferreira PCS, Haas VJ. Quality of life of elderly. Comparison between urban and rural areas. Invest Educ Enferm. 2014;32(3):401-13.

29. Bilgili N, Arpacı F. Quality of life of older adults in Turkey. Arch Gerontol Geriatr. 2014;59(2):415-21. 